\title{
EXPLORING THE NARRATIVE OF HERITAGE THROUGH THE EYES OF THE LAW
}

\section{Lee Jing}

Institute for Environment and Development (LESTARI), Universiti Kebangsaan Malaysia, MALAYSIA

E-mail: leejing@ukm.edu.my

Published online: 29 December 2017

To cite this article: Lee, J. 2017. Exploring the narrative of heritage through the eyes of the law. Kajian Malaysia 35(Supp.1): 185-207. https://doi.org/10.21315/km2017.35.Supp.1.10

To link to this article: https://doi.org/10.21315/km2017.35.Supp.1.10

\begin{abstract}
The need to protect and safeguard the world's heritage has emerged as a concern for the international community as the deterioration, damage and destruction of both tangible and intangible heritages are seen to be on the increase. The outstanding universal values of the natural and cultural heritage reflect the deepseated interdependence between the tangible and intangible domains of heritage, rendering them unique and irreplaceable, thus necessitating conservation as it is a reflection of humanity. "Heritage" is a difficult concept to define. Determining what heritage "is" and to whom something is considered a "heritage", is a highly subjective, value-oriented exercise, contingent on the individuals, groups and communities who in various ways, had identified themselves with, and related themselves to the heritage. This article explores the narrative of the normative landscape of heritage conservation and its progressive development. The discussion adopts a discursive approach in interpreting the heritage discourse as codified in the relevant international legal instruments. An inquiry into the dynamic interpretation of "heritage" couched in the imperative to protect and to safeguard both tangible and intangible heritages is important in supporting the efforts towards conservation of heritage. This will ultimately enable a legacy to be left that could be inherited by future generations.
\end{abstract}

Keywords: intangible cultural heritage, common heritage of mankind, heritage conservation, heritage law, heritage narrative 


\section{HERITAGE CONSERVATION}

...Heritage should be regarded more as a verb rather than a noun; "heritage" is something we do, rather than something that is...

(Staiff, 2014).

The protection, conservation and safeguarding of the world's heritage have emerged as concerns for the international community as the deterioration, destruction and damage of both tangible and intangible heritage are seen to be on the rise. The waves of emotions, abhorrence, horror, loss and sorrow experienced when heritage is lost to armed conflict and war, natural disasters and unchecked development are real. Anger and remorse cut the deepest when the wanton destruction of heritage, especially in the last few decades in Timbuktu, Palyra in Syria, Lebanon, Yemen, Libya, Pakistan, and Afghanistan, was caused by "a cornucopia of zealots" (Parker, 2016).

On 27th September 2016, the International Criminal Court (ICC) Trial Chamber VIII in The Hague sentenced Al Faqi Al Mahdi to nine years imprisonment over the destruction of a mosque and nine of Timbuktu's World Heritage Sitelisted mud-built shrines (UNESCO World Heritage Centre, 2016a; ICC, 2016b). He was found guilty of attacking the historic and religious buildings in Timbuktu and the ICC convicted him for committing a war crime. The ICC opined that the mausoleums of saints and mosques of Timbuktu are not only religious buildings, but that they also hold symbolic and emotional values for the people of Timbuktu (ICC, 2016a). The ICC further asserted that the attacks appeared to be exceptionally grave as these mausoleums and mosques were an integral part of the religious life of its inhabitants, and constitute a common heritage for the community (ICC, 2016a). The destruction did not only affect the direct victims of the crimes; that is, the people of Timbuktu who perceived the religious buildings as their protector, but also the people throughout Mali and the international community.

It is such representation of the identity and dignity of a community that rendered the heritage a target of cultural or ethnic cleansing, with destruction increasingly used as a means to magnify the impact of war. These attacks on cultural heritage are seen as a deliberate extermination of identities and memories, causing great mental anguish. In addition to being treated as war crimes, it should also be considered a crime against humanity for its attempt to dehumanise and devalue, making it comparable to a crime of persecution or genocide (Bevan, 2016).

The coupling of heritage with values, and the association of heritage to communal legacies that imprinted the footsteps of the community's forefathers, drive the community's desire to preserve the memory of the home where their heart belongs. It is a form of personalised setting organised and represented in ways that are capable of allowing individuals to realise self-regulating principles, 
and in facilitating these individuals to maintain self-coherence and self-esteem (Dixon and Durrheim, 2000). Likewise, Matsuura (2002) deemed that the coupling of heritage and value also serves as vectors of identity, values and meaning that represent the richness and diversity of culture and the plurality of values and identities within societies that are themselves diverse and plural.

A discursive approach is adopted to help reveal the narrative of heritage couched in the language of law, which will address the question of "what is heritage and to whom it belongs to". These legal texts are taken as the concretisation of the discursive processes of heritage that is alive and living, aligned with the conceptualisation of heritage as a story constructed through the selective canonisation of episodes of culture intentionally woven by the authority empowered to determine the version of the story to be told. This narrative is explored through the Convention Concerning the Protection of World Cultural and Natural Heritage (WHC) ${ }^{1}$ and the Convention for the Safeguarding of the Intangible Cultural Heritage 2003 (ICHC). ${ }^{2}$

\section{A DISCURSIVE APPROACH TO THE CONSTRUCTION OF THE NARRATIVE OF HERITAGE}

Cultural diversity is the manifestation of humans' innate instincts to associate themselves with their natural and cultural environment, and the instinctive inclination to preserve the creative expression of man in a setting in which they could remain to live "...in contact with nature and the evidences of civilisation bequeathed by past generation". ${ }^{3}$ If heritage is construed as a representation and voices that speak from the past, a cultural discourse of heritage that constructs the narrative of heritage would necessarily stem from the fundamental aspect of cultural diversity (Jokilehto, 2006).

The discursive practice of heritage is one of the ways in which a society constructs itself through its collective social memory. The "storying" of each and every individual and family in the society converges into a single but coherent narrative and subsequently unfolding into a "tradition" that connects a relation between the past, community and identity, within the structure of its narrative, in an authoritative manner (Scott, 1999). A heritage process describes the ways in which individuals act, interact, feel, believe and value, together with other people, through the use of various sorts of symbols, objects, tools and technologies to recognise him or herself and the others as meaningful in certain ways (Gee, 2005). As such, the exploration of the narrative of heritage, particularly in questioning what heritage is, and to whom it belongs, gives bearing to the construction of the on-going process of understanding heritage and its indigenous meanings (the meaning-making) as defined by the custodians of the heritage (Hall, 1997), which can be approached through a regime of discourse (Hou and $\mathrm{Wu}, 2012$ ). 
The diversity of culture and the plurality of value that shape the narrative of heritage render the determination of what heritage "is" and to whom it is considered a "heritage", a highly subjective, value-oriented exercise (Labadi, 2013). It is contingent on the individual, groups and communities who in various ways, identify with, and relate themselves to the heritage.

The concrete noun of heritage as a discourse emphasises the peculiarity of the context and the uniqueness of representing aspects of the world of an area of experience, from a particular perspective (Fairclough, 2006). The discussion of what is heritage proceeds on the understanding of "heritage", by adopting the expansive scope proffered by Hall (2005) which encompasses a gamut of the complex of organisations, institutions and practices devoted to the preservation and presentation of culture and the arts, as well as sites of special historical interest that are either cultural, natural or both.

It is important to approach heritage from a broad perspective. This is because of the operation of selective tradition, that is the storying of heritage made by relevant institutions with the authority, the material and institutional facticity to define the selective canonisation of episodes of culture into a selective tradition, which corresponds to the current system of interest and values (Williams, 2001). It also reflects the prevailing assumptions of its time and context imposed by the power and the authority of the versions of history that are meaningful, or episodes of history that are considered to be important (Hall, 2005).

Understanding the foundations that foreground the construction of "heritage" is important as the process is a construction of the past in the present. "Making the past present for the future" (Halimaton et al., 2013) involves an act of recognition in the present (Lowenthal, 1985), of an inheritance from an artificially constructed past for current use, which decides on what should be passed on to a future imagined in the present (Tunbridge and Ashworth, 1996). When heritage is increasingly acknowledged to be a discursive practice, a discursive approach is appropriate to enable a critical understanding of what heritage is, and to whom the discursive practice of heritage belonged. A discursive approach facilitates the unravelling of dimensions in which the heritage is constructed, identified, interpreted, valued, conserved, managed and used (Wu and Hou, 2015), through the cluster of related methods for studying of language use and its role in influencing social life (Potter, 2008).

Following the crystallisation of Fairclough's three-dimensional concept of discourse that comprises a complex of the three elements of socio-cultural practices, discursive practices and texts (Fairclough, 1995), and the understanding of heritage as a social practice, it would inevitably assume a semiotic element; the concretisation of a discursive practice of heritage in text (Fairclough and Wodak, 1997; Fairclough, 2001; Martin and Wodak, 2003; Fairclough, 1995). Understanding the ways in which the shaping and the transformation of social, 
cultural and historical realities are woven into the narrative of heritage is key. These are reflected in language choices and the ways language is deployed for the codification of heritage narrative into legal text (Wu and Hou, 2015).

A review of the dominant force in constructing a discourse on heritage conservation at the global level and the role of the United Nations Educational, Scientific and Cultural Organisation (UNESCO) ${ }^{4}$ in spearheading the conservation and safeguard of the world's tangible and intangible cultural and natural heritage is critical. It is incumbent to interpret the major legal instruments that formalised and institutionalised the discursive practice of heritage to glean an insightful exploration of the narrative of heritage.

\section{THE FORMALISATION OF HERITAGE CONSERVATION IN LAW}

The law could be viewed both as a regulatory apparatus, and as a vital axis that articulates the tangible and intangible vestiges of the past. By virtue of the iterative process of law-making, the concept of heritage is defined and redefined as it is articulated and framed in legal classification, and perpetuated in law over time (Soderland, 2009). The manner in which certain values are ascribed to law, and the particular historical snapshot captured in the legal text, provide a window to those who have, and have not participated in determining and informing as to what "heritage" is and to whom it belongs.

The adoption of the WHC on 16 November 1972 marked the first formal recognition of an international community regarding the harmful impoverishment of the heritage of all nations in the world as a consequence of a formidable wave of deterioration, damage, and destruction that struck the world's cultural and natural heritage. UNESCO had advocated a particular approach and a series of common and universal underlying values that have now formed part of "common, universal language" of today's heritage conservation (Harrison, 2013; Silva, 2015). In order to understand what entails in the protection and safeguarding of heritage and contextualising it within the remit in which heritage "belongs", an inquiry is necessary. This includes exploring the normative landscape and progressive development of the concept of heritage; as well as measures to conserve and safeguard within selected UNESCO Conventions.

The WHC and the ICHC are selected for the purpose of exploring the narrative of heritage through the eyes of the law. These Conventions provide a broad and general framework for conservation and safeguard of tangible and intangible aspects of world heritage. They are a suitable starting point for a study to reveal the implicit dimension that structures the obligation to conserve and safeguard heritage, as well as to unravel the discursive practices that construct the narrative. The interpretation of the heritage discourse reflected and realised in 
the text conforms to Fairclough's (1995) three-dimensional conceptualisation of discourse.

This article interprets the legal text stipulating for the conservation and safeguard of heritage using the general rule of interpretation of treaties (Gardiner, 2015). The interpretation of the text is also informed by the scholarships on the theory of discourse whereby an inter-textual reading of the relevant texts is deployed to ascertain which social, cultural and historical identities, realities, and the power relations between people and systems of knowledge are weaved into the fabric of the discourse on heritage (Niemi-Kiesiläinen et. al., 2007; Fairclough, 1996). The attempt to bring together perspectives from the legal and social science disciplines in exploring to whom the story belongs to, as well as how and by whom the story has been told would be instrumental in discerning the epistemological relationship and interaction between legal norms and social facts.

\section{A NORMATIVE NARRATIVE OF HERITAGE AND ITS CONSERVATION CRYSTALLISED IN THE LAW}

The definition of "heritage" as adopted in the beginning of this article is reiterated here. Heritage is defined as the whole complex of organisations, institutions and practices devoted to the preservation and presentation of culture and the arts, and sites of special historical interest. The recurring themes that influence and shape the discourse of heritage would be the interpretation of:

1. The whole complex of organisations and institutions, with emphasis on the authority endowed with the power to conduct selective canonisation of the episodes of culture they think mattered, here the World Heritage Committee under the WHC, and the Intergovernmental Committee under the ICHC are looked at;

2. The practices devoted to the preservation and presentation of culture and the arts. This refers to the discursive practices of heritage conservation, from the internal recognition of a socio-cultural practice as a heritage by the custodians to the submission for inscription to the Convention bodies. This includes the decision- or policy-making processes, including the assessment and selection processes, and the criteria in interpreting what constitute "Outstanding Universal Value (OUV)". In the case of the ICHC, instead of the standard of OUV, the standard for inscription deployed is, a proposed inscribed element should be capable of contributing to "ensuring visibility and awareness of the significance of the intangible cultural heritage and to encouraging dialogue, thus reflecting cultural diversity worldwide 
and testifying to human creativity". The exploration of the socio-cultural dynamics implicit in the explicit texts of law that seeks to answer the question of "to whom the heritages belong to?" highlights the element of inclusivity in the determination of the course of a heritage discourse; and

3. The sites of special historical interest, that mark the ultimate objective of heritage protection and safeguard, posing the question of "what is the listing of the sites of special historical interest for?"; which follows the question of "what is heritage". The answering of "what is heritage" charts the entire discursive practices of heritage as captured in the heritage narrative crystallised in the texts of law.

\section{The Whole Complex of Organisations and Institutions}

\section{The World Heritage Convention 1972}

The WHC is a comprehensive legal document establishing an effective system for collective protection of the cultural and natural heritage of outstanding universal value in accordance with modern scientific methods that put the protection and preservation of both cultural and natural heritage under one umbrella on a permanent basis (UNESCO, 1972). It combines the two tangible heritages representing the combined works of nature and of man, which is a reminder of the intertwined relationship between people and nature in a cultural landscape and the need to strike a balance between them (UNESCO World Heritage Centre, 2016b).

Article 4 of the WHC stipulates an obligation for state parties to the Convention to ensure, the identification, protection, conservation, presentation and transmission to future generations of the cultural and natural heritage as defined under Articles 1 and 2, situated on national territories, and belonging primarily to the State (UNESCO, 1972). They need to do this, as much as they possibly could, with their own resources and where appropriate, with any international assistance and cooperation obtained. The stipulations in the Convention are overseen by an Intergovernmental Committee for the Protection of the Cultural and Natural Heritage of Outstanding Universal Value (known as the World Heritage Committee) established within UNESCO. ${ }^{5}$ In overseeing the implementation of the obligations at the national level, the WHC requires that state parties set up one or more services for the protection, conservation and presentation of the cultural and natural heritage with an appropriate staff that possess the means to discharge their functions within its territories, in order to ensure that effective and active measures have been taken for the protection, conservation and presentation of the cultural and natural heritage at the national level. ${ }^{6}$ 
Article 8 of WHC further provides the election of 21 state members to the Committee on a six-year term. The selection of the members is to be based on an equitable representation of the different regions and cultures of the world. Representatives of the International Centre for the Study of the Preservation and Restoration of Cultural Property (Rome Centre), the International Council of Monuments and Sites (ICOMOS) and the International Union for Conservation of Nature and Natural Resources (IUCN) also serve as members of the Committee. Invitations to sit in an advisory capacity may be extended to intergovernmental and non-governmental organisations with similar objectives upon the request of State Parties to the Convention.

The Committee has multiple roles, with the main role being to establish, update and publish the World Heritage List, and whenever circumstances require to also publish a list of World Heritage in Danger. This contributes directly to the heritage discourse, as there is a requirement to identify the criteria on the basis of which a property belonging to the cultural or natural heritage may be included in either lists. This includes deciding on the inscription of a site of OUV on the World Heritage List, subject to the consent of the relevant state in the event of inclusion, and to consult with the state party in question in the event of a refusal of the request for inclusion into one of the two Lists. ${ }^{7}$

\section{The Intangible Cultural Heritage Convention 2003}

The ICHC, as stated in Article 1(a), seeks to safeguard the intangible cultural heritage considered to be a common heritage of mankind, a heritage as essential to humanity as the importance of biodiversity is to nature. "Safeguard", in the context of ICHC, means "...measures aimed at ensuring the viability of the intangible cultural heritage, including the identification, documentation, research, preservation, protection, promotion, enhancement, transmission, particularly through formal and non-formal education, as well as the revitalisation of the various aspects of such heritage". 8

In order to achieve this, the ICHC, by providing international cooperation and assistance, aspires to:

1. Ensure respect for the intangible cultural heritage of the communities, groups and individuals concerned;

2. Raise awareness at the local, national and international levels of the importance of the intangible cultural heritage; and

3. Ensure mutual appreciation for intangible heritage.

For carrying out its purpose, the ICHC has defined "intangible cultural heritage" to mean "...the practices, representations, expressions, knowledge, 
skills - as well as the instruments, objects, artefacts and cultural spaces associated therewith - that communities, groups and, in some cases, individuals recognise as part of their cultural heritage". The ICHC acknowledged that heritage could be manifested in a non-exhaustive list of domains consisting of "...oral traditions and expressions, including language as a vehicle of the intangible cultural heritage; performing arts; social practices, rituals, and festive events; knowledge and practices concerning nature and the universe; and traditional craftsmanship". ${ }^{9}$

The sovereign body of the ICHC, as provided in Article 4, is the General Assembly of the States Parties, with the Intergovernmental Committee for the Safeguarding of the Intangible Cultural Heritage, comprising 24 elected Committee members in the General Assembly, assisting in overseeing the implementation of the ICHC. It has the mandate, to carry out the core functions of the promotion of the objectives. ${ }^{10}$ It is also to encourage as well as monitor the implementation of the ICHC.

The Intergovernmental Committee is tasked with establishing the selection criteria for the inscription of intangible cultural heritage submitted by state parties into the Representative List of the Intangible Cultural Heritage of Humanity and the List of Intangible Cultural Heritage in Need of Urgent Safeguarding. ${ }^{11}$ This is in addition to the selection and promotion of national, sub-regional and regional programmes, projects and activities, which it considers would best reflect the principles and objectives of the ICHC.

THE ICHC provides that, it is also the task of the Intergovernmental Committee to examine requests for international assistance from state parties for the preparation of such proposals and to decide on the granting of international assistance for the preparation of such proposal. ${ }^{12}$ The effective implementation of the Convention at the national level is overseen by "one or more competent bodies for the safeguarding of the intangible cultural heritage present in its territory" which imposes the establishment of a formal institution, tasked with the implementation of the obligations laid out in the ICHC at the national level. ${ }^{13}$

\section{The Discursive Practice of Heritage Conservation}

The discursive practice of heritage conservation is contingent on the institutions of decision-making established under these Conventions. Members holding offices in the Committees are involved in the decision-making process that determines the perspectives, ways and manners in which a heritage is constructed, as well as ascertains what constitutes "heritage". Thus, it is incumbent to analyse the mechanisms in which the discursive practice of heritage is undertaken as codified in the text of law, with an emphasis on the mechanisms for the assessment and selection of OUV of a submission, and the subsequent implementation of protection and safeguard measures. 


\section{Criteria for Inscription}

Under the WHC, the World Heritage Committee is mandated to develop and to constantly revise the set of ten criteria that guides the selection of cultural and natural heritage sites to be included on the World Heritage List. It elaborates the threshold of OUV for the inscription of cultural and natural heritages into the World Heritage List. ${ }^{14}$

The OUVs are defined in the 2016 Operational Guidelines ("Guidelines") at Paragraph 49, to mean "cultural and/or natural significance which is exceptional as to transcend national boundaries and to be of common importance for present and future generations of all humanity" (UNESCO World Heritage Centre, 2016b). Ten criteria for the assessment of a property as having OUV are set out as per Paragraph 77 of the Guidelines, and standard for OUV is achieved when one or more criterion is met. In addition, the conditions of integrity and/or authenticity as set out in Schedule 2 of the Guidelines must be met. Measures for adequate protection and management system for safeguard, as per Paragraph 78 of the Guidelines, must also be in place.

The emphasis on the most outstanding of all properties of great interest, importance or value at the national and/or regional level from an international viewpoint, as stipulated in the Guidelines, endows the World Heritage Committee with the power to determine the types of heritage considered to be so outstanding and exceptional, that they are of common importance for present and future generations of all humanity transcending national boundaries. Worth noting is the fact that they have the power to determine what would render a heritage to be of common importance for the present and future generations of the humanity.

In the case of the ICHC, the Operational Directives of the ICHC prescribe for the assessment criteria for the inscription of an intangible cultural heritage into the Representative List of the Intangible Cultural Heritage of Humanity. ${ }^{15}$ Apart from the requirement that submission for inscription into the List "...constitutes intangible cultural heritage as defined in Article 2 of the (ICH) Convention", it is further specified that the submission should demonstrate that the inscription of the element will "...contribute to ensuring visibility and awareness of the significance of the intangible cultural heritage and to encouraging dialogue, thus reflecting cultural diversity worldwide and testifying to human creativity". ${ }^{16}$ The procedural nature of other criteria of assessment elucidates the normative framework for the interpretation of the imperative to obtain the recognition of the custodians of the cultural element proposed for inscription that the element forms part of their cultural heritage in the assessment of whether a cultural element constitutes an intangible cultural heritage. ${ }^{17}$ 


\section{The Dynamics of the Socio-Cultural Practices of Heritage}

The engagement of custodians; individuals, groups and communities living in the area in which a heritage is located, to whom the heritage gives a sense of belonging and identity, and with whom the heritage shares a deep spiritual, emotional and social links, is important in ensuring the effectiveness, efficiency and sustainability of a conservation effort (Deisser and Njuguna, 2016; Amareswar, 2009). The WHC does not expressly provide for the requirement to involve the communities and custodians of the proposed heritage properties in the preparation of the nomination.

However, the recognition that communities are the focal point of the discursive practice of heritage was translated in the Budapest Declaration on World Heritage (Budapest Declaration), adopted at the 26th Session of the Bureau of the World Heritage Committee in 2002 (UNESCO, 2002a). The World Heritage Committee took note of this assertion of a value-laden ideology that brings the people back to the centre of tangible heritage conservation by revising its Strategic Objectives in light of the Budapest Declaration by adding a Fifth $\mathrm{C}$, that is the "Communities" to the existing Strategic Objectives of Credibility, Conservation, Capacity Building and Communication.

The Fifth $\mathrm{C}$ was read as, "...to enhance the role of communities in the implementation of the World Heritage Convention" where all interested parties are encouraged to promote and implement this fifth Objective (UNESCO, 2007). The Operational Guidelines strengthened the emphasis on communities where it stipulated for the participation of "...a wide variety of stakeholders, including site managers, local and regional governments, local communities, NGOs and other interested parties and partners" (UNESCO World Heritage Centre, 2016b). The Budapest Declaration is a positive move, taken in recognition of the members of the World Heritage Committee of the universality of the WHC as an instrument that promotes the sustainable development of all societies through dialogue and mutual understanding. At the same time it acknowledges the increasing challenges in the protection of the shared heritage that should be held in trust to pass on to the future generations as their rightful inheritance. The Declaration is also mindful that there is a need to ensure the local communities at all levels are actively involved in the identification, protection and management of the world heritage properties.

Unlike the WHC, since the inception of ICHC community engagement has always been at the centre of the safeguarding of an intangible cultural heritage. The ICHC requires the state parties to engage the communities, groups and individuals in the effort to safeguard the intangible cultural heritage. The elements of participation, social inclusion and mobilisation are apparent in the ICHC. Heavier emphasis is placed on involving the people, especially the members of society with direct relations to the elements constituting the intangible cultural heritage. This is to be done at the time of submission for inscription into the list, 
and during the selection and promotion of programmes, projects and activities for the safeguarding of intangible cultural heritage.

It is apparent that civil society, especially the custodians of the intangible cultural heritage, has a much bigger role in the discursive process of the construction of the narrative of an intangible cultural heritage, within the ICHC. The stronger emphasis on the civil society is manifested in a separate obligation on state parties to "...endeavour, by all appropriate means, to - ensure [the] recognition of, respect for, and enhancement of the intangible culture heritage in society". ${ }^{18}$ This would be done through various education, awareness-raising and information programmes aimed at the general public especially the young people; specific education and training programmes within communities and groups; capacity-building activities in management and scientific research for the safeguarding of the intangible cultural heritage; and other non-formal means of knowledge transmission. ${ }^{19}$

Based on the overview in the preceding section regarding the discursive practices codified in the instruments of law, and in determining the authority that has been given the power to impose its idealisation of what constitutes heritage, it could be seen that the law that defines what heritage means and to whom it belongs to incorporates an interactional process of law-making. The reciprocal relationships between the lawmakers and the subjects of law (Fuller, 1969) in which state parties play a dual role - dédoublement fonctionnel as both the lawmakers and the subjects of law (Cassese, 1990), are explicitly structured into the normative landscape that charts the discourse of "heritage". This means, the normative landscape that shapes the dimensions of "heritage" is provided in the text of the law that:

1. Establishes the process of nomination by state parties of what they consider to be inscribable to the Lists of the Conventions;

2. Determines whether the nominations for inscription into the List should be approved as assessed against the criteria prescribed;

3. Arrives at a decision regarding the nominations; and if successful,

4. Ensures continuous conformation to the requirements of protection and safeguarding as prescribed under the Conventions.

In an attempt to answer the question "to whom a heritage belongs to", reference would have to be made to the members of the enterprise of law-making that constructs the narrative of law, and the subjects of law-making that assimilate a certain construction of law in a practice of legality. The members of this enterprise are the authority that decides the selective canonisation of the version of heritage deemed appropriate, taking into account the institutional dynamics of the WHC General Assembly consisting of state parties, the managing organs, and the relevant 
actors who participated in the law-making process whether directly or indirectly; and the subjects of the law-making. This includes state parties, communities, civil society, and custodians who confirm or negate the version of a construction of a heritage, and subsequently mould and shape the discourse of heritage through their continual engagement with the heritage. This interactional account of law brings the discussion to the interpretation, in its context, of "what is heritage?" which is addressed in the subsequent section.

\section{Sites of Special Historical Interests}

As noted earlier, heritage is a dynamic, living process, intertwined with the fluxes of cultural traditions practised in the community. The direction in which a discourse on heritage develops depends on the landscape of discursive practices in an interactional process that constantly reinterprets and reconstructs the narrative of heritage, and its protection and safeguard. Drawing inspirations from the concept of place-identity that "...attends to the located nature of subjectivity", and as articulated by Dixon and Durrheim (2000), the interpretation would take place in the normative and empirical spheres of the context as captured in the phrase of the grounds of identity, which depicts a sense of belonging to a place and a rhetorical expression of the legitimation of a particular social practice and relations.

The notion of place-identity is especially relevant to the prevailing discussions of "what is a heritage?", which is intimately related to "whom it belongs to", and seems to revolve around the recurring issue of "what is heritage for?". Strong ideological messages underpinning the duty of the international community to protect, conserve, present and transmit the cultural and natural heritage to future generations was asserted by the World Heritage Centre:

Heritage is our legacy from the past, what we live with today, and what we pass on to future generations. Our cultural and natural heritages are both irreplaceable sources of life and inspiration. They are our touchstones, our points of reference, our identity.

(UNESCO, 2008)

The significance and importance of the functionality of heritage as a legacy from the past as quoted above is its ability to imbue man with a sense of identity and continuity, ${ }^{20}$ instilling in them a sense of awe at the resilience of man and the ingenuity of human creativity. This emotive element decides whether the "...works of man or the combined works of nature and of man, and areas including archaeological sites which are of OUV from the historical, aesthetic, ethnological or anthropological points of view" in a cultural heritage site warrants an inscription into the World Heritage List. ${ }^{21}$ 
In other words, as stated in Article 1 of the Universal Declaration on Cultural Diversity, 2001 (UDCD), heritage is the manifestation of the uniqueness and plurality of the identities of the groups and societies that make up humankind (UNESCO, 2002b). Articles 2 and 3 of the UDCD further states the instrumental role it plays as a source of exchange, innovation, creativity that doubles up as a platform that promotes the flourishing of creativity that sustains public life. This enables the harmonious interactions between people and groups with plural, varied and dynamic cultural identities crucial in ensuring social cohesion, the vitality of civil society, and peace, and most of all, widens the options of the peoples endeavouring to achieve a more satisfactory, intellectual, emotional, moral and spiritual existence (UNESCO, 2002b). It is this functionality that attracts the consideration that the tangible and intangible heritages of mankind should be treated as the common heritage of humanity.

However, an interpretation of a heritage would have to take place within the systemic environment in which the heritage is situated. Bakker (2011) argued that since the meaning of heritage is socially constructed, complex, and multifaceted, the interpretation of laws that preserve and present the vessels of values embedded in a heritage should be geared towards achieving heritage topographies that represent open-ended transmitters of meaning, knowledge, emotion, and experience where inclusiveness is the dominant narrative. This compels a construction of "what is a heritage" in its systemic environment via the exploration of the normative landscape captured in the text of law (ILC, 2006; McLachlan, 2005; French, 2006).

Just as the dawn of heritage tourism where heritage is treated as a resource, criticisms regarding disruptions in a community's societal fabric, displacements of locals, and the uproot of current cultural practices that brought about its inscription in the first place began to take root (Staiff and Bushell, 2013; Reeves and Plets, 2016). This leads to the subsequent development in other fields of law that would influence and shape the interpretation of legal concepts concerning heritage couched in the text of the law.

Recourse to the scholarship on inter-textuality reveals the interconnected vocabularies and systems of meaning located in the social world that built the culture of social behaviour. The reference to similar words identifying "heritage" could be found in at least three areas of international law. The first, International Humanitarian Law, via the treaty regimes of, among others, the Rome Statute $1998^{22}$ and The Hague Convention $1954^{23}$ that prohibits the wanton destruction of cultural properties, religious, charitable, educational, and historic buildings and monuments during war, all of which are directly, if not indirectly connected with the conceptualisation of heritage. Secondly, International Human Rights Law, especially in the identification and qualification of an intangible cultural heritage to only refer to the heritages that are "compatible with existing human 
rights instruments, as well as with the requirements of mutual respect among communities, groups and individuals, and of sustainable development" as per Article 2(1) of the ICHC. This, in turn, links with International Environmental Law and International Development Law that address questions of law relating to sustainable development, most notably in the conservation of natural heritage that could be found under environmental law, natural resources law and heritage law.

In addition, a proposal by the ICHC Intergovernmental Committee made at the Tenth Session of the Intergovernmental Committee, 2015 in favour of the communities, groups and individuals, has paved the way for the introduction of the principle of access and benefit sharing into the paradigm of intangible cultural heritage safeguard (Jacobs, 2016). Custodians of intangible cultural heritage have to ensure that they have benefitted, or obtained benefit "...from the protection of the moral and material interests resulting from such heritage, and particularly from its use, research, documentation, promotion or adaptation by members of the communities or others" (Jacobs, 2016).

A concerted body of law concerning the discursive practices of heritage conservation is seen to have emerged through the perpetuation of law via a rule-based framework as well as judgement made in reliance to the standard of correctness structured by these rules. The ability of the language of law described by Erll (2011) as a "re-integrative inter-discourse", reconnects in a single space the manifold discrete parlances about the past, contributes towards the systemic integration of the normative framework of heritage predominantly codified in the major UNESCO Conventions. The language of law could be found in the list of UNESCO Conventions relevant to heritage and its conservation such as:

1. Convention for the Protection of Cultural Property in the Event of Armed Conflict with Regulations for the Execution of the Convention 1954;

2. Convention on the Means of Prohibiting and Preventing the Illicit Import, Export and Transfer of Ownership of Cultural Property 1970;

3. Convention on the Protection of the Underwater Cultural Heritage 2001; and

4. Convention on the Protection and Promotion of the Diversity of Cultural Expression Convention 2005.

Coherence and consistency in jurisprudence could be achieved in view of the substantive connections between the Conventions, especially the WHC and ICHC as both Conventions address issues relating to the definition of heritage; the deep-seated interdependence between tangible and intangible heritage; and the protection and safeguard of heritage for the benefit of the whole of humanity. Analogising international law relating to heritage protection and safeguard as "a universe of inter-connected islands" (Pauwelyn, 2004), the use of a consistent and 
integrated interpretation of the obligation to protect and safeguard heritage could contribute towards enhancing the uniformity and unity of international law, and ultimately, strengthen the corpus juris gentium as a whole.

If heritage is indeed, understood as "...our legacy from the past, what we live with today, and what we pass on to future generations" (UNESCO, 2008), we are merely stewards holding these world heritages in trust for future generations. An interpretation of the principle of the common heritage of mankind from the perspective of a theoretical foundation based on intra- and inter-generational equity that has roots in the concepts of stewardship and trusteeship, originated from notions of natural justice. It could be used to ensure that these resources are not exploited for personal gains or appropriation, but to be preserved in the interest of the whole of humanity, centred on the principle of justice (Baslar, 1998; Tarlock, 1992).

As it stands, and as of 31 January 2017, there are 193 state parties to the WHC, with 1,052 properties from 165 parties inscribed into the Representative List, comprising 34 heritage properties that are transboundary, 814 cultural heritage, 203 natural heritage, and 35 mixed heritage (UNESCO World Heritage Centre, n.d.). There are only two delisted heritage sites: Germany's Dresden Elbe Valley in 2009 and Oman's Arabian Oryx Sanctuary in 2007. Similarly, a strong international participation of 172 state parties in the ICHC indicates an almost universal acceptance of the ICHC's paradigm on intangible cultural heritage (UNESCO Intangible Cultural Heritage, n.d.). The report of the Secretariat of ICHC to the Sixth Session of the General Assembly of State Parties to the Convention in 2016 stated that since 2008 a total of 81 elements have been inscribed to the Representative List, with more than 90 safeguarding plans developed and submitted to the Secretariat during the reporting period (UNESCO Intangible Cultural Heritage, 2016).

The almost universal membership to the two Conventions provides the empirical evidence of the international community's agreement of, and conformity to, the prevailing paradigm of heritage discourse and its processes entailed in the construction and interpretation of heritage. The active participation of the international community in furthering the objectives of these two Conventions indicates the congruence between the practice of legality undertaken by the state parties in accordance with the standard of correctness provided by the Conventions.

The continuous engagement of state parties and support demonstrated through relatively concomitant and consistent state practices with the basic norm, are illustrative of an interactive and dynamic discursive practice in the construction of a heritage discourse. This is evident in the measures that set the standard of OUV, authenticity and integrity of a heritage inscription; the framework of actions relevant to the protection and safeguard of heritage; and the decision-making processes connected to the implementation of the objectives of the protection and 
safeguard of heritage in general as well as the effective implementation of the Conventions.

Apart from the ascertainment of "the context" that necessitates the identification of the place-identity which gives meaning to the heritage, the dynamics of the arena of actions, where there is congruence between the obligations stipulated under the law and the practice of legality performed by the subjects of lawmaking (especially the state parties), could also be observed. Taking into account the systemic environment where interpretation of the rules of international law pertaining to heritage takes place, another area of debate crucial to the construction of the context that charts the legal narrative is the inextricable interdependence between tangible and intangible heritages, as well as the interlinkages, be they substantial, procedural, or institutional between the WHC and ICHC.

Despite some criticisms posed against the conflation of WHC with ICHC, where scholarship demands that "thou shalt not confuse" the two (Jacobs, 2016), the intertwined nature of tangible and intangible heritage is given explicit recognition in the Preamble of ICHC. It describes the dynamic development of an intangible cultural heritage as a discursive process that is "constantly recreated by communities and groups in response to their environment, [and] their interaction with nature and their history", which marks the interwoven and interconnected relations between both tangible and intangible dimensions of heritage. The inescapable corollary where it is the intangible of meanings tied to a tangible physicality that endow a heritage its OUV renders the distinction between tangible and intangible artificial (Kurin, 2004).

\section{CONCLUSION}

The exploration of the narrative of heritage through the eyes of the law entails a construction of the meaning of heritage, as seen from the lens of heritage being a subject of progressive, dynamic socio-cultural discourse. In this article, the social construct of heritage is unravelled through the analytical prisms of:

1. The authority with the power to tell the story of heritage;

2. The reciprocal relations between the members of the law-making enterprise and the subjects of law-making who develop the law through the interactional process of confirmation and/or dissonance; and

3. The context in which the multiple spheres of the socio-cultural and discursive practices of heritage converge to give meanings to a particular heritage in a particular place that shares a particular identity. 
They are then interpreted against the systemic environment in which the context is situated.

The construction and meaning-making of the concept of heritage through a discursive approach revealed that, law did not lay down a definitive normative scope and substance of heritage capable of answering the question of "what is heritage?"; nor did it answer to the question of "to whom the heritage belongs to?". Instead, as demonstrated through the exploration of the narrative of heritage couched in the language of law, it laid down the basic norm, the framework of actions, and the processes that foreground the construction of heritage, which charts the progressive development of the heritage discourse, making heritage a dynamic, living process.

Bearing in mind the significance of heritage as a legacy from that past, to be passed to the future generations, its wilful destruction is an affront to the values upheld by the education of humanity for justice, liberty, and peace, all of which are indispensable to the dignity of man (UNESCO, 1945). Hence, the protection of the common heritage of mankind constitutes a sacred duty that should be fulfilled by all nations.

\section{ACKNOWLEDGEMENTS}

This research is undertaken under the Fundamental Research Grant Scheme awarded by the Ministry of Higher Education, Government of Malaysia (Research Grant No.: FRGS/1/2014/STWN09/UKM/02/1). The author would like to extend her appreciation to the Langkawi Research Centre (PPL) and the Institute for Environment and Development (LESTARI), Universiti Kebangsaan Malaysia (UKM) for the support provided in facilitating the research.

\section{NOTES}

1. Convention Concerning the Protection of the World Cultural and Natural Heritage (adopted 16 November 1972, entered into force 15 December 1975) 1037 UNTS 151 (hereinafter "WHC").

2. Convention for Safeguarding of the Intangible Cultural Heritage (adopted 17 October 2003, entered into force 20 April 2006) 2368 UNTS 1 (hereinafter "ICHC").

3. Recommendation Concerning the Protection, at National Level, of the Cultural and Natural Heritage 1972 (adopted 16 November 1972, entered into force 17 December 1975).

4. Constitution of the United Nations Educational, Scientific and Cultural Organization (adopted 16 November 1945, entered into force 4 November 1946, London).

5. Article 8, WHC 1972. 
6. Article 5(b), WHC 1972.

7. Article 11, WHC 1972.

8. Article 2(3), ICHC 2003.

9. Article 2(1) and (2), ICHC 2003.

10. Article 7(a), ICHC 2003.

11. Articles 16 and 17, ICHC 2003.

12. Article 18, ICHC 2003; and Article 22 to be read together with Article 7(g), ICHC 2003.

13. Article 13, ICHC 2003.

14. Article 11, WHC 1972.

15. UNESCO, "Basic Texts of the 2003 Convention for the Safeguarding of the Intangible Cultural Heritage. 2016 Edition". http://www.unesco.org/culture/ich/doc/ src/2003_Convention_Basic_Texts-_2016_version-EN.pdf (accessed 24 November 2017)

16. Item R.1, paragraph 1.2; and Item R.2, Paragraph 1.2(2), Chapter 1, Basic Texts of the 2003 Convention 2016.

17. Article 2(1), ICHC 2003.

18. Article 14, ICHC 2003.

19. Article 14, ICHC 2003.

20. Article 2(1), ICHC 2003.

21. Article 1, ICHC 2003.

22. Statute of the International Criminal Court (concluded 17 July 1998, entered into force 1 July 2002) 2187 UNTS 90 (hereinafter "The Rome Statute").

23. Convention for the Protection of Cultural Property in the Event of Armed Conflict 1954 (concluded 14 May 1954, entered into fore 7 August 1956) 249 UNTS 240 (hereinafter "The Hague Convention on Cultural Property").

\section{REFERENCES}

Amareswar, G. 2009. The "first voice" in heritage conservation. International Journal of Intangible Heritage (3): 10-25.

Bakker, K. A. 2011. Heritage as transmission: Toward achieving a more dominant narrative of inclusion. Heritage and Society 4(2): 239-252. https://doi.org/10.1179/ hso.2011.4.2.239.

Baslar, K. 1998. The concept of the common heritage of mankind in international law. Leiden: Martinus Nijhoff Publishers.

Bevan, R. 2016. Attacks on culture can be crimes against humanity. The Art Newspaper. 27 September. http://old.theartnewspaper.com/comment/attacks-on-culture-canbe-crimes-against-humanity/ (accessed 15 May 2017).

Cassese, A. 1990. Remarks on Scelle's theory of "role-splitting" (dédoublement fonctionnel) in International Law. European Journal of International Law 1: 210-231. https://doi.org/10.1093/oxfordjournals.ejil.a035763. 
Deisser, A-M and M. Njuguna, eds. 2016. Conservation of natural heritage in Kenya. A cross-disciplinary approach. London: UCL Press. https://doi. org/10.14324/111.9781910634844.

Dixon, J. and K. Durrheim. 2000. Displacing place-identity: A discursive approach to locating self and other. British Journal of Social Psychology 39: 27-44. https:// doi.org/10.1348/014466600164318.

Erll, A. 2011. Memory in culture. Translated by Sara B. Young. London: Palgrave Macmillan (Palgrave Macmillan Memory Studies). https://doi.org/10.1057/9780230321670.

Fairclough, N. and R. Wodak. 1997. Critical discourse analysis. In Discourse as social interaction, ed. T. A. van Dijk, 258-284. London: Sage.

Fairclough, N. 2006. Language and globalization. London: Routledge.

. 2001. The discourse of new labour: Critical discourse analysis. In Discourse as data: A guide for analysis, eds. M. Wetherell, S. Taylor and S. J. Yates, 229-266. London: Sage.

1996. Discourse and social change. Cambridge: Polity Press.

1995. Critical discourse analysis: The critical study of language. London and New York: Longman.

French, D. 2006. Treaty interpretation and the incorporation of extraneous legal rules. International and Comparative Law Quarterly 55: 281-314. https://doi. org/10.1093/iclq/lei082.

Fuller, L. L. 1969. Human interaction and the law. American Journal of Jurisprudence 14: 1-36. https://doi.org/10.1093/ajj/14.1.1.

Gardiner, R. K. 2015. Treaty interpretation. Oxford: Oxford University Press.

Gee, P. 2005. An introduction to discourse analysis: Theory and method. 3rd ed. London and New York: Routledge.

Hall, S. 2005. Whose heritage? Un-settling "The heritage", re-imagining the post-nation? In The Politics of heritage: The legacies of "race", eds. J. Littler and R. Naidoo, 23-35. London and New York: Routledge.

Hall, S. 1997. The work of representation. In Representation: Cultural representations and signifying practices, ed. S. Hall, 13-74. London: Sage.

Harrison, R. 2013. Heritage: Critical approaches. London and New York: Routledge. https://doi.org/10.1093/oxfordhb/9780199602001.013.021.

Halimaton Saadiah Hashim, Rahimah Abdul Aziz, Sarah Aziz, Ong Puay Liu and K. L. Chan@Geraldine, eds. 2013. Pelan pengurusan Langkawi Geopark PPLG 20122030. UKM Bangi: Penerbit LESTARI.

Hou, S. and Z. Wu. 2012. Discourse analysis and the interpretation of indigenous meanings of Chinese cultural heritage: A case study of the Wenchang Palace. Southeast Culture 4: 21-27.

ILC. 2006. Report of the study group of the international law commission. Fragmentation of international law: Difficulties arising from the diversification and expansion of international law (Finalised by Martti Koskenniemi) (Fifty-Eight Session, 1 May-9 June and 3 July-11 August 2006, Geneva). UN Doc A/CN.4/L.682. 13 April. http://legal.un.org/ilc/guide/1_9.shtml (accessed 15 May 2017). 
International Criminal Court (ICC). 2016a. ICC Trial Chamber VIII declares the war crime of attacking historic and religious buildings in Timbuktu and sentences him to nine years imprisonment. (ICC-CPI-20160927-PR1242) https://www.icc-cpi.int/ pages/item.aspx?name=pr1242 (accessed on 15 May 2017).

2016b. Case Information Sheet. The Prosecutor v Ahmad Al Faqi Al Mahdi. ICC01/12-01/15. https://www.icc-cpi.int/mali/al-mahdi/Documents/Al-MahdiEng. pdf (accessed 15 May 2017).

Jacobs, M. 2016. The spirit of the convention - Interlocking principles and ethics for safeguarding intangible cultural heritage. International Journal of Intangible Heritage 11: 72-87.

Jokilehto J. 2006. World heritage: Defining the outstanding universal value. City \& Time 2(2): 1 http://www.ct.ceci-br.org (accessed 15 May 2017).

Kurin, R. 2004. Safeguarding intangible cultural heritage in the 2003 UNESCO Convention: A critical appraisal. MUSEUM 56(1-2): 66-77.

Labadi, S. 2013. UNESCO, cultural heritage, and outstanding universal value. Valuebased analyses of the world heritage and intangible cultural heritage conventions. Lanham, New York, Toronto, Plymouth: Alta Mira Press.

Lowenthal, D. 1985. The past is a foreign country. Cambridge: Cambridge University Press.

Martin, J. and R. Wodak. 2003. Introduction. In Re/reading the past: Critical and functional perspectives on time and value, eds. Martin, R. and R. Wodak. Amsterdam: John Benjamins. https://doi.org/10.1075/dapsac.8.

Matsuura, K. 2002. Cultural diversity: A vision. The cultural wealth of the world is its diversity in dialogue. In UNESCO, Universal declaration on cultural diversity: A vision, a conceptual platform, a pool of ideas for implementation, a new paradigm. Cultural Diversity Series No. 1, World Summit on Sustainable Development, Johannesburg. 26 August-4 September. http://unesdoc.unesco.org/ images/0012/001271/127162e.pdf (accessed 15 May 2017).

McLachlan, C. 2005. The principle of systemic integration and Article 31(3)(c) of the Vienna Convention. International and Comparative Law Quarterly 54: 279-330. https://doi.org/10.1093/iclq/lei001.

Niemi-Kiesiläinen, J., P. Honkatukia and M. Ruuskanen. 2007. Legal texts as discourses. In Exploiting the limits of law. Swedish feminism and the challenge to pessimism, eds. A. Gunnarsson, E. Svensson and M. Avies. Aldershot: Ashgate Publishing.

Parker, M. 2016. Irrational war on cultural heritage. New Straits Times. 5 September. http://www.nst.com.my/news/2016/09/170844/irrational-war-cultural-heritage (accessed 15 May 2017).

Pauwelyn, J. 2004. Bridging fragmentation and unity: International law as a universe of inter-connected islands. Michigan Journal of International Law 25(4): 903-916.

Potter, J. 2008. Discourse analysis. In The SAGE Encyclopedia of qualitative research methods, ed. L. Given, 217-220. London: Sage.

Reeves, K. and G. Plets. 2016. Cultural heritage as a strategy for social needs and community identity. In A companion to heritage studies, eds. Logan, W., M. N. Craith and U. Kockel, 203-214. Chichester: Wiley Blackwell (Blackwell Companions to Anthropology). 
Scott, D. 1999. Re-fashioning futures; criticism after post-coloniality. New Jersey: Princeton.

Silva, K. D. 2015. Paradigm shifts in global heritage discourse. Space and Communication 1(1):1-15. https://doi.org/10.15340/2148172511880.

Soderland, H. A. 2009. The history of heritage: A method in analysing legislative historiography. In Heritage studies methods and approaches, eds. M. L. S. Sørensen and J. Carman. London and New York: Routledge.

Staiff, R. 2014. Reimagining heritage interpretation. Enchanting the past-future. London and New York: Routledge.

Staiff, R. and R. Bushell. 2013. Mobility and modernity in Luang Prabang, Laos: Rethinking heritage and tourism. International Journal of Heritage Studies 19(1): 98-113. https://doi.org/10.1080/13527258.2011.646287.

Tarlock, A. D. 1992. Stewardship sovereignty. Washington University Journal of Urban and Contemporary Law 42: 21-27.

Tunbridge, J. E. and G. J. Ashworth. 1996. Dissonant heritage: The management of the past as a resource in conflict. Chichester: John Wiley.

UNESCO. 2015. The Tenth Session of the Intergovernmental Committee for the Safeguarding of the Intangible Cultural Heritage (Windhoek, Namibia, 30 November to 4 December 2015) ITH/15/10.COM/15.a (15 October 2015, Paris). https://ich.unesco.org/en/Decisions/10.COM/15.a (accessed 15 May 2017). 2008. World heritage information kit. Paris: UNESCO World Heritage Centre. 2007. Decisions Adopted at the 31st Session of the World Heritage Committee (World Heritage Committee of the Convention Concerning the Protection of the World Cultural and Natural Heritage, Christchurch, New Zealand, 23 June-2 July 2007) WHC-07/31.COM/24 (31 July 2007, Paris). http://whc.unesco.org/ archive/2007/whc07-31 com-24e.pdf (accessed 15 May 2017).

2002a. Decisions Adopted by the 26th Session of the World Heritage Committee regarding World Heritage Committee of the Convention Concerning the Protection of the World Cultural and Natural Heritage, Budapest, 24-29 June 2002 (Budapest Declaration). WHC-02/CONF.202/25 1 August 2002. UNESCO, Paris. http:// whc.unesco.org/archive/2002/whc-02-conf202-25e.pdf (accessed 15 May 2017). 2002b. Universal Declaration on Cultural Diversity. Cultural Diversity Series No.1. http://portal.unesco.org/en/ev.phpURL_ID=13179\&URL_DO=DO_ TOPIC\&URL_SECTION=201.html (accessed 15 May 2017).

1973. Recommendation Concerning the Protection, at National Level, of the Cultural and Natural Heritage, 1972, 146-154. http://unesdoc.unesco.org/ images $/ 0011 / 001140 / 114044$ e.pdf\#page $=145$ (accessed 14 October 2017).

1972. Convention Concerning the Protection of the World Cultural and Natural Heritage. http://portal.unesco.org/en/ev.php-URL_ID $=13055 \& U R L \_D O=D O$ _ TOPIC\&URL_SECTION=201.html (accessed 15 May 2017).

1945. UNESCO Constitution. http://portal.unesco.org/en/ev.php-URL_ID=15244 $\& U R L \_D O=D O \_T O P I C \& U R L \_S E C T I O N=201 . h t m l$ (accessed 15 May 2017). 
UNESCO Intangible Cultural Heritage. 2016. Report of the Secretariat on Its Activities (Sixth Session of the General Assembly of the State Parties to the Convention, 30 May to 1 June 2016, Paris). https://ich.unesco.org/doc/src/ITH-16-6.GA-6-EN. docx (accessed 15 May 2017).

. 2003. Texts of the Convention for the Safeguarding of the Intangible Cultural Heritage. https://ich.unesco.org/en/convention (accessed 15 May 2017)

n.d. The State Parties to the Convention for the Safeguarding of the Intangible Cultural Heritage (2003). https://ich.unesco.org/en/states-parties-00024 (accessed 22 November 2017).

UNESCO World Heritage Centre. 2016a. Timbuktu Trial: A major step towards peace and reconciliation in Mali. 27 September. http://whc.unesco.org/en/news/1559/ (accessed 15 May 2017).

. 2016b. Operational Guidelines for the Implementation of the World Heritage Convention. http://whc.unesco.org/en/guidelines/ (accessed 15 May 2017).

.n.d. Frequently asked questions (FAQ). http://whc.unesco.org/en/faq/46 (accessed 15 May 2017).

Williams, R. 2001. The long evolution. 2nd ed. Ontario: Broadview Press.

$\mathrm{Wu}, \mathrm{Z}$. and S. Hou. 2015. Heritage and discourse. In The Palgrave handbook of contemporary heritage research, eds. E. Waterton and S. Watson, 37-51. UK: Palgrave Macmillan (Palgrave History Collection). https://doi. org/10.1057/9781137293565_3. 